\title{
Determination of Relationships of Nurses' Professional Commitment to Organizational, Work and Family Commitment by Structural Equation Model
}

\author{
Hemşirelerin Mesleki Bağ|ılıkları ille Örgůtsel, İş ve Aile Bağ|ılıkları Arasındaki \\ İlişkilerin Yapısal Eşitlik Modeli île Belirlenmesi
}

\author{
Assoc. Prof. Dr. Serap Benligiray - Assoc. Prof. Dr. Harun Sönmez
}

\begin{abstract}
The commitment forms of individuals regarding their private and work lives have been subject to various researches in an independent or interactive way. In this study, a model has been developed and tested for defining the relationship between the nurses' professional commitment and organizational, work and family commitment. The study was conducted with the nurses employed in 7 state hospitals with 500 or over bed capacity and 3 medicine faculties under the body of Ankara Ministry of Health through questionnaires. 355 nurses were chosen via proportional distribution method in stratified sampling. The relationship between work commitment scale and continuance commitment part of the organizational commitment scale and the relationship between family commitment scale and professional commitment scale are not significant. Except for the correlation between professional commitment scale and affective commitment part of the organizational commitment scale, the correlations are quite weak.
\end{abstract}

Keywords: Organizational Commitment, Personnel Administration, Professional-Family Relations, Nursing

\section{Öz}

Bireylerin özel ve iş yaşamlarına ilişkin bağhllık formları ya birbirinden bağımsız ya da birbirleriyle etkileşimli olarak çeşitli araştırmalara konu olmuştur. Bu çalışmada da bu konuda daha önceden yapilan araștırmalar ışığında hemşirelerin mesleki bağllıkları ile örgüte, işe ve aileye bağhllıkları arasındaki ilişkiyi tanımlamaya yönelik bir model geliştirilmiş ve test edilmiştir. Çalışma, Ankara'da Sağlık Bakanlığına bağlı 500 ve üzeri yataklı 7 devlet hastanesi ile 3 tıp fakültesinde çalışan hemşirelerle anket yoluyla görüşülerek yapılmıştır. Çaışma evreni içinden 355 hemşire, tabakalı örneklemede orantılı dağıtım yöntemi kullanılarak belirlenmiştir. Ișe bağlllık ölçeği ile örgütsel bağlllı ölçeğinin devam bağllĭğı kısmı arasındaki ilişki ve aileye bağlllık ölçeği ile mesleki bağlllik ölçeği arasındaki ilişki ve mesleğe bağhllık ölçeği ile aileye bağhllik ölçeği arasındaki ilişki anlamlı değildir. Mesleğe bağlllık ölçeği ile örgüte bağlılık ölçeğinin duygusal bağlllık kısmı arasındaki korelasyon dişındaki korelasyonların oldukça zayıf olduğu görülmektedir.

Anahtar Kelimeler: Örgütsel Bağlllık, Personel Yönetimi, İş-Aile İlişkileri, Hemşirelik

\section{Introduction}

Each profession requires its all members a deep commitment, which goes beyond the desire of earning money. This commitment is especially important for the professions such as health, military and education which cannot be easily supervised by third parties and necessitate to take vital and urgent decisions (Weick and McDaniel, 1989, p.331-354). The nurses active in health sector tend to be more professional compared to other sectors due to reasons such as their education, scientific knowledge background, long years of experience, professional organizations, and so on. Such a tendency makes nurses see their jobs as

Assoc. Prof. Dr. Serap Benligiray, Anadolu University Faculty of Economics and Administrative Sciences, sbenligi@anadolu.edu.tr Assoc. Prof. Dr. Harun Sönmez, Anadolu University Open Education Faculty, hsonmez@anadolu.edu.tr 
a carrier field (like in academicians, scientists, doctors, lawyers and engineers). This goes beyond doing a specific job, and stems from being a member of an organization in which such a work is performed (Blau, 1985, p.277-288).

The professional commitment of professionals has an undeniable strong effect on the outcomes of the work. Most probably, this is a bigger effect than organizational or work commitment since professionals proceed with their professional expectations rather than their organizational expectations (Cohen, 2000, p.387417). Therefore, it is very important to develop the professional commitment of the nurses. We believe that among the variables affecting the professional development, the other commitment forms also play an important role. It is necessary to know whether the professional commitments of the individuals are affected from their organizational, work and family commitment, and how the interactive relationships between these commitment forms are. This will not only contribute to literature but also enable to see the other commitment forms that the professional commitments of nurses are affected from.

\section{Theoretical Background}

\section{Relationship Between Professional Commitment and Organizational Commitment}

Professional commitment occurs when an individual believes in the necessity and importance of the profession he chose, and volunteers to continue belonging to this profession (Vanderberg and Scarpello, 1994, p.535-547). In this case, the individual has dedicated himself to his profession and carrier, and believed in and accepted all the ethic rules and goals of the profession (Lachman and Aranya, 1986, p.227-243). This way, individuals with professional commitment are more willing to stay in the profession, accept its goals and values, and exert effort for it.

Organizational commitment, which holds a key role in the relationship between the individual and the organization, is used to define a psychological commitment covering involvement in the work, loyalty and belief in the organizational values. There are three types of commitment as dealt in this research: Affective commitment defines the emotional state of the personnel in terms of uniting with the organization, identification and showing loyalty. Normative commitment depends on the perception of the personnel regarding the commitment to his duty and organization. Continuance commitment reflects the perceptions of the personnel regarding the cost of leaving the organization such as losing working conditions, membership, and so on (Meyer and Allen, 1997, p.234-275).

The researchers conducted so far have revealed that organizational commitment and professional commitment are two separate concepts (e.g. Billingsley and Cross, 1992, p.453-471; Firestone and Pennell, 1993, p.489-525; Paullay, et al., 1994, p.224-228; Cohen, 1999, p.285-308; Manheim and Papo, 2000, p.119-137). Organizational commitment occurs as a result of the attachment or identification of the individual with the organization he works in (Mathieu and Zajac, 1990, p.171-194). However, professional commitment takes place when the effort of an individual for developing skills and expertise in a specific field begins to gain importance and have a central place in his life (Greenhouse, 1971, p.209-216).

Organizational commitment and professional commitment are important to accomplish the organizational goals, achieve the professional development of the nurses and improve their performances. However, there may be a clash between these two commitment forms in practice (Bredeson, et al., 1983, p.52-58; Igbaria, 1991, p.141-171; Firestone and Pennell, 1993, p.489-525; Wallace, 1993, p.333-349; Carson, et al., 1996, p.273-286). According to Tuma and Grimes (1981, p.187-206), professional commitment should have a negative relationship with organizational commitment since professional value system requires professional independence, compliance with the professional standard and ethic values, collegial supervision, customer- orientation and professional loyalty. Organizational commitment, on the contrary, values obeying the organizational arrangements and norms and being loyal to the organization. Professional values and organizational values do not always match. Therefore, it is less likely to feel high commitment to the organization for an individual who is more committed to his profession and its goals (Wallace, 1993, p.333-349).

Although there are some studies which indicate that organizational and professional commitment can be independent from each other in the literature (e.g. 
Grimes, 1980, p.195-211; Friedlander, 1971, p.169183; Berger and Grimes, 1973, p.223-235; Flango and Brumbaugh, 1974, p.198-210), it can be asserted that professional commitment and organizational commitment are related with each other, and this relationship is in a negative way. Unlike the studies in the literature, the model formed in this study takes organizational commitment in three dimensions rather than one because each commitment dimension (affective, normative and continuance) happens as a result of different experiences, and these have different effects on work behaviors (Meyer, et al., 2002, p.20-52). Therefore, it is possible that each sub-dimension affects professional commitment and work commitment differently. In this respect, in their research conducted in England, Snape and Redman (2003, p.152-159) found out a relationship between the intention of being involved in professional activity and affective commitment and a relatively lower ratio of normative commitment. No statistically significant relationship was found between continuance commitment and the intention of being involved in a professional activity.

\section{Relationship Between Professional Commitment and Work Commitment}

Work commitment makes an individual dedicate himself to ongoing works (Becker, 1960, p.32-42) and identify with the work (Dubin, 1956, p.131-142). Further, it can be suggested that work commitment includes evaluations of the individual regarding the virtues and meaning of the work (Lodahl and Kejner, 1965, p.24-33). In work commitment, it is of great importance for the individual to stick to the work and feel psychologically attached to his work even if not satisfactorily (Rusbult and Farrel, 1983, p.429-438). Moreover, work commitment is related to intrinsic motivation rather than extrinsic (Lawler and Hall, 1970, p.305-312). Work commitment is a tendency, which includes the beliefs about a work, and to what extent a work meets the needs of an individual. However, work commitment is generally a normative belief about the value of a work in an individual's life, and more of a function of the earlier cultural or socialization state (Kanungo, 1982, p.341-349). Some research show that individuals with relatively lower professional attachment are more likely to be unsatisfied with their jobs and think about quitting the job (Koeske and Koeske, 1993, p.107-135). In the Meta analysis performed by Lee, et al. (2000, p.799-811), work commitment was found related to professional commitment at a medium level as well as the other variables.

It is important to understand the structure of interior relationships between work commitment and other commitment forms (Morrow, 1993, p.206-307). In the model developed by Randall and Cote (1991, p.194-211), they suggested that work commitment has an important compatible role in the interior relationships with other commitment forms. It was further suggested that work commitment directly and deeply affect both organizational commitment and carrier path. Therefore, the model we developed includes the relationship of work commitment with organizational commitment and family commitment in addition to professional commitment.

\section{Relationship Between Work Commitment and Organizational and Family Commitment}

Work commitment and organizational commitment are two different but interrelated attitudes (Morrow, 1983, p.486-500). In most of the studies, a positive and medium level relationship was found between work commitment and organizational commitment (e.g. Cook and Wall, 1980, p.39-52; Parasuraman and Nachman, 1987, p.287-303; Blau and Boal, 1989, p.115-127; Knoop, 1995, p.643-649; Taşkıran and Özcan, 2007, p.402-500; Buchko, et al., 1998, p.109-116; Ceylan and Demircan, 2002, p.1-13). It was observed that individuals with high level of organizational commitment tend to have high level of work commitment (e.g., Porter, et al., 1976, p.87-98; Thomas, 2002, p.143-286).

In literature, there are many studies conducted to reveal the commitments of individuals to work and family life roles and the interactions between these commitments. This issue can be regarded important since it points at the time and energy relationship. It is assumed that individuals generally spend more time and energy on the roles they highly value because these rare resources are limited. In this case, the work or family role commitment level of the individual would affect the amount of the time and energy he wants to exert for that role (Frone, et al., 1992, p.65-78) and his sensitivity for the role (Higgins, et al., p.51-75). It is anticipated that a person highly committed to his 
work would fail to fully perform his family role or vice versa (Wiley, 1987, p.467-472). Therefore, one of the important factors to consider while interpreting the effects of family life variables on work or organizational commitment is how individuals rank the importance of their roles regarding their work and family lives (Zin, 2006, p.117-121).

In theory, it is asserted decrease in commitment is inevitable when a role clash is experienced (Morris and Sherman, 1981, p.512-526). It is difficult for an individual to be highly committed to his profession and/or work and family at the same time, and this situation generally leads to a stressful clash (See Rice, 1979, p.164-205; Price-Bonham and Murphy, 1980, p.181-188; Skinner, 1983, p.90-101). Moreover, a negative relationship was found out between the carrier satisfaction of the individuals and experiencing work-family clash in some studies (Powell and Mainiero, 1992, p.215-237; Tenbrunsel, et al., 1995, p.233-246; Stroh, et al., 1996, p.99-118; Martins, et al., 2002, p.399-409).
Additionally, in some studies, it is asserted that there is a strong relationship between work commitment and experiencing work-family clash (Higgins, et al., 1992, p.51-75; Allen, et al., 2000, p.278-308; Frone, 2003, p.143-162). While a weak statistically significant relationship was found out between work commitment and work-family clash in some studies (Carmeli, 2003, p.788-813), no statistically significant relationship could be found between these two variables in one study (Samuel, 2007, p.551-560). This situation naturally will make a difference when the professional commitment of an individual is at the minimum level (Aldous, et al., 1979, p.227-325).

\section{The Model and Hypotheses of the Research}

In this research, the model displayed in Figure 1. was developed and tested for the relationship between professional commitment, organizational commitment, work commitment and family commitment.

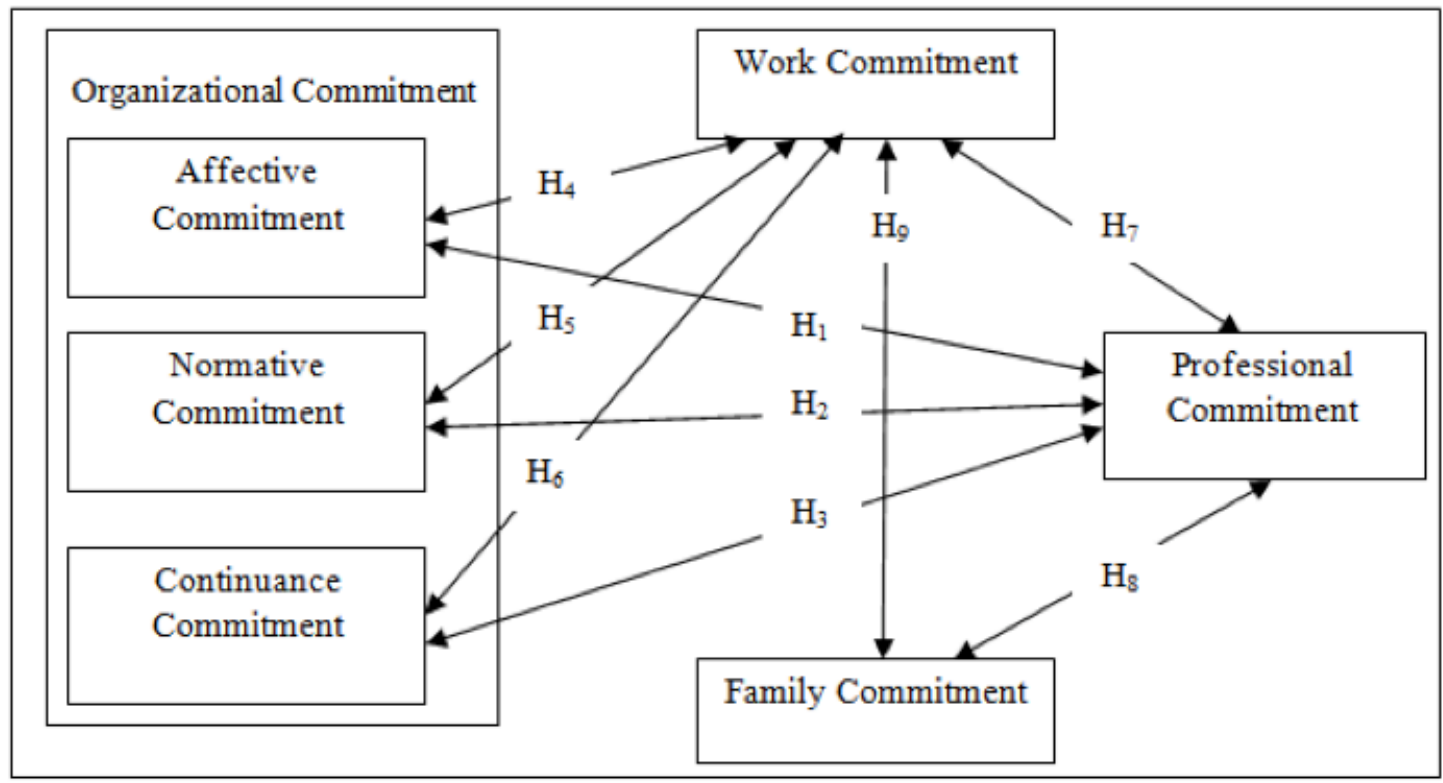

Figure 1. The Model for the Relationship between Professional Commitment and the other Commitment Forms 
The hypotheses below were established in the model developed:

$\mathrm{H}_{1}$ : There is a relationship between affective commitment dimension and professional commitment.

$\mathrm{H}_{2}$ : There is a relationship between normative commitment dimension and professional commitment.

$\mathrm{H}_{3}$ : There is a relationship between continuance commitment and dimension professional commitment.

$\mathrm{H}_{4}$ : There is a relationship between affective commitment and dimension work commitment.

$\mathrm{H}_{5}$ : There is a relationship between normative commitment and dimension work commitment.

$\mathrm{H}_{6}$ : There is a relationship between continuance commitment dimension and work commitment.

$\mathrm{H}_{7}$ : There is a relationship between work commitment and professional commitment.

$\mathrm{H}_{8}$ : There is a relationship between family commitment and professional commitment.

$\mathrm{H}_{9}$ : There is a relationship between work commitment and family commitment.

\section{Methods}

\section{Sample}

The study was conducted with the nurses employed in 7 state hospitals with 500 or over bed capacity and 3 medicine faculties under the body of Ankara Ministry of Health through questionnaires. In the study, 355 nurses were chosen via proportional distribution method in stratified sampling. The questionnaires were administered with the help of Performance Management and Quality Development Chamber at the hospitals under the body of Ministry of Health and with the efforts of researchers at medicine faculties.

\section{The Questionnaire Survey}

The scale developed by Blau (1985, p.277-288) was used to measure the professional commitment of the nurses. The professional commitment scale includes eight items such as "I want to make a carrier in nursing" and "Given the chance, I would again choose to be a nurse". The three dimensioned scale developed by Meyer and Allen (1991, p.61-89) was used to measure the organizational commitment of the nurses. The affective commitment part of the scale includes six items such as "I see the problems of my institution as if they were mine" and "I feel strongly attached to the institution I work for"; the normative commitment part includes five items such as "This institution deserves my loyalty" and "I would feel guilty if I left this institution now"; and the continuance part includes six items such as "It is more of a necessity than desire to stay in this institution" and "Leaving this institution now would cost money loss in my future life".

The scale developed by Blau (1985, p.277-288) was used to measure the work commitment of the nurses. The work commitment scale has nine items such as "Everything about my work is very important to me" and "Most of my life goals are work-oriented". The scale developed by Yogev and Breetts (1985, p.754768) was used to measure the family commitment of the nurses. The family commitment scale has eight items such as "The most important reason for my satisfaction in life is my family" and "The most important events I experience are about my family". Since three items in the professional commitment scale and an item in work commitment scale are in negative form, they were reversed during coding. Each item of the scales is answered by choosing an option ranging from "I strongly disagree" to "I strongly agree" (1-5).

\section{Data Analysis}

In this study, Structural Equation Modeling (SEM) was used. SEM is generally used to find out the reliability of a model thought to have interrelated variables. This technique is a systematic tool used to evaluate the relationships between the variables and test the hypothetical models in psychology, sociology, marketing and educational sciences (Joreskog and Sörbom, 2001, p.101-215).

SEM is an extensive statistical technique used to test the causal relationships between the observable and latent variables. It was proved that this technique is useful for solving the problems encountered in formulating the hypothetical constructs (Reisinger and Turner, 1999, p.71-88).

Technically, SEM is used in predicting the unknown parameters in linear construct equation set. The variables in equations are generally directly observed variables and latent variables related with the observed variables. SEM presupposes that there is a causal 
structure between the latent variables set, and the latent variables can be measured through the observed variables (MacLean and Gray, 1998, p.2-5).

There are many different goodness of fit indexes to evaluate the appropriateness of the model developed. The most commonly used and proposed ones are chi-square similarity rate statistic (CMIN/DF), root mean square error approximation (RMSEA) and goodness of fit (GFI) indexes. When chi-square similarity rate statistics has a value below 3 , the match is in an acceptable level. When RMSEA has a value equal to or lower than 0,05 , the match is excellent, and when the same value is equal to or lower than 0,08 , it also shows that there is an acceptable match. GFI takes a value between 0 and 1 , and values of 0,95 or above show that the match is excellent while the values between 0,90 and 0,94 show there is an acceptable match (Cheng, 2001, p.650-667; Pang, 1996, p.64-83; Schermelleh-Engel and Moosbrugger, 2003, p.23-74).

The statistical analysis of the data was performed in SPSS PASW Statistics 18.0 and SEM Amos 16.0 package programs.

\section{Results}

The demographic features of the 355 nurses who participated in the study are given below in Table 1.

\begin{tabular}{|c|c|c|}
\hline Variables & Total Number of Nurses & $(\%)$ \\
\hline \multicolumn{3}{|l|}{ Age } \\
\hline 19 or below 19 & 1 & 0,3 \\
\hline $20-29$ & 93 & 26,2 \\
\hline $30-39$ & 183 & 51,5 \\
\hline $40-49$ & 75 & 21,1 \\
\hline $50-59$ & 3 & 0,9 \\
\hline \multicolumn{3}{|l|}{ Education } \\
\hline High School & 58 & 16,3 \\
\hline Degree Program & 176 & 49,6 \\
\hline Faculty & 111 & 31,3 \\
\hline Master and $\mathrm{PhD}$ & 10 & 2,8 \\
\hline \multicolumn{3}{|l|}{ Marital Status } \\
\hline Single & 96 & 27,0 \\
\hline Married & 246 & 69,3 \\
\hline Widowed & 2 & 0,6 \\
\hline Divorced & 11 & 3,1 \\
\hline \multicolumn{3}{|l|}{ Number of Children } \\
\hline 1 & 125 & 35,2 \\
\hline 2 & 95 & 26,8 \\
\hline 3 & 4 & 1,1 \\
\hline 4 & 0 & 0,0 \\
\hline 5 or over 5 & 1 & 0,3 \\
\hline No & 130 & 36,6 \\
\hline \multicolumn{3}{|l|}{ Work Status of Spouse } \\
\hline Working & 233 & 65,6 \\
\hline Do Not Working & 16 & 4,5 \\
\hline I do not have a spouse & 106 & 29,9 \\
\hline
\end{tabular}

The interior consistency coefficients of the scales used in the study were evaluated with Cronbach's Alpha, and the results are presented in Table 2. The Cronbach's Alpha value is between 0 and 1. The Cronbach's Alpha values of the scales used in the research indicate that these scales are close to total reliability.
The measures regarding the appropriacy of the research model presented in Figure 1 and the results are given below in Table 3 .

The results displayed in Table 3 indicate that the model has an acceptable match. The covariance analysis results and correlations regarding the research model are given in Table 4. 
Table 2. The Interior Consistency Coefficients of the Scales

\begin{tabular}{lc}
\hline \multicolumn{1}{c}{ Scales } & Cronbach's $\boldsymbol{\alpha}$ Value \\
\hline Professional commitment (PC) & 0,621 \\
Affective commitment (Affec.OC) & 0,842 \\
Normative commitment (Nor.OC) & 0,761 \\
Continuance commitment (Con.OC) & 0,592 \\
Work commitment (WC) & 0,837 \\
Family commitment (FC) & 0,769 \\
\hline
\end{tabular}

According to the results presented in Table 4, the relationship between work commitment scale and continuance commitment part of the organizational commitment scale and the relationship between family commitment scale and professional commitment scale are not statistically significant in 5\% significan-
Table 3. The Measures Regarding the Appropriacy of the Model and their Results

\begin{tabular}{lc}
\hline \multicolumn{1}{c}{ Metric } & Value \\
\hline CMIN/DF & 2,23 \\
RMSEA & 0,06 \\
GFI & 0,79 \\
\hline
\end{tabular}

ce level. Except for the correlation between professional commitment scale and affective commitment part of the organizational commitment scale, the correlations are quite weak. The correlations between the scales are given in Figure 2.

Table 4. The Covariance Analysis Results and Correlations Regarding the Research Model

\begin{tabular}{lcccc}
\hline & Estimate & S.E. & $\mathbf{r}$ & $\mathbf{p}$ \\
\hline PC $<--->$ WC & 0,06 & 0,02 & 0,43 & $0,01^{*}$ \\
WC $<--->$ Affec.OC & 0,18 & 0,04 & 0,39 & $0,00^{*}$ \\
WC $<--->$ Nor.OC & 0,14 & 0,03 & 0,35 & $0,00^{*}$ \\
WC $<--->$ Con.OC & 0,00 & 0,03 & 0,00 & 0,95 \\
PC $<--->$ Affec.OC & 0,06 & 0,02 & 0,65 & $0,01^{*}$ \\
PC $<--->$ NorOC & 0,03 & 0,01 & 0,36 & $0,01^{*}$ \\
PC $<--->$ Con.OC & $-0,03$ & 0,01 & $-0,22$ & $0,03 *$ \\
PC $<--->$ FC & 0,00 & 0,00 & $-0,07$ & 0,28 \\
WC $<--->$ FC & 0,05 & 0,02 & 0,14 & $0,02 *$ \\
\hline
\end{tabular}

${ }^{*}$ It is statistically significant in $5 \%$ significance level.

\section{Discussion}

For long years, the commitment forms of individuals regarding their private or work lives have been subject to various studies independently or interactively. In this study, a model was developed and tested to define the relationship between the nurses' professional, organizational, work and family commitment in the light of the previous studies on this subject. As a result of the test, seven hypotheses out of nine were rejected $\left(\mathrm{H}_{1}, \mathrm{H}_{2}, \mathrm{H}_{3}, \mathrm{H}_{4}, \mathrm{H}_{5}, \mathrm{H}_{7}, \mathrm{H}_{9}\right)$ while two were accepted $\left(\mathrm{H}_{6}\right.$ and $\left.\mathrm{H}_{8}\right)$ and the model gained its final version (see, Figure 2).

Although some of the previous studies on the relationship between organizational commitment and professional commitment assert that there is no relationship between these two concepts (e.g. Friedlander, 1971, p.169-183; Berger and Grimes, 1973, p.223235; Flango and Brumbaugh, 1974, p.198-210), many studies suggested that there is a negative relationship between organizational commitment and professional commitment (Tuma and Grimes 1981, p.187-206; Bredeson, et al., 1983, p.52-58; Igbaria, 1991, 141171; Firestone and Pennell, 1993, p.489-525; Wallace, 1993, p.333-349; Carson, et al., 1996, p.273-286). Unlike these studies, our study considered organizational commitment in three dimensions rather than one dimension, and yielded different outcomes than these studies. According to the results, there is a strong positive relationship between affective commitment to 


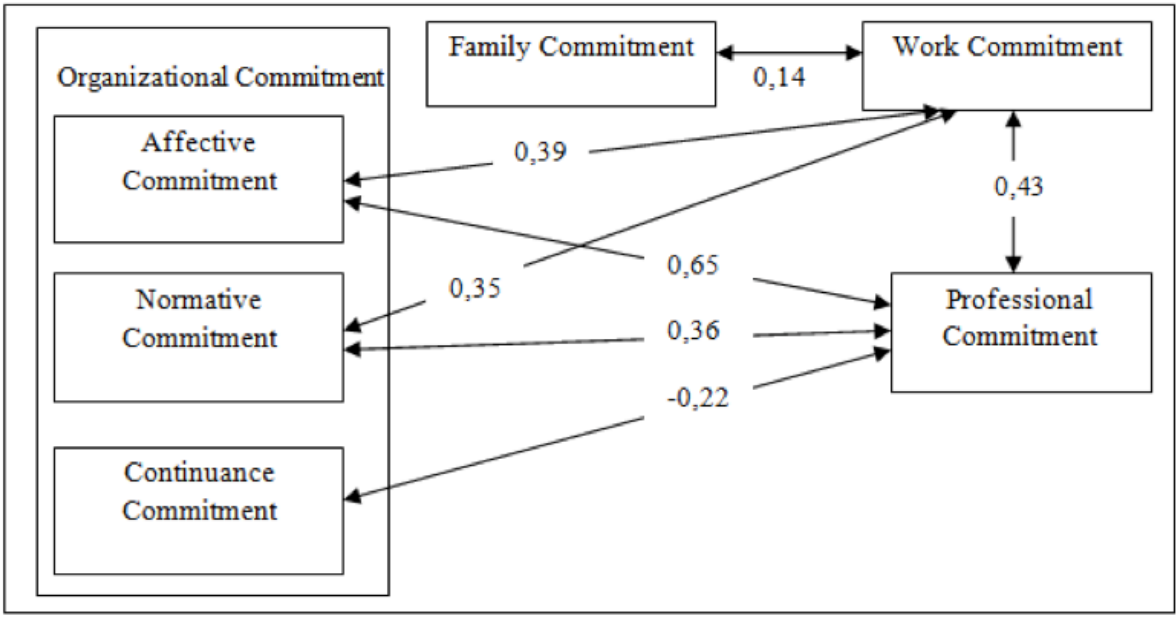

Figure 2. Results of Structural Estimations

the organization and professional commitment. While there is a weak positive relationship between normative commitment and professional commitment, there is a negative weak relationship between continuance commitment and professional commitment.

A great number of people want to choose a profession appropriate for their skills, work at a job appropriate for the profession they have chosen, and make a carrier in their profession during their work lives. Therefore, the opportunity to get promoted and develop is one of the important motivations for people to participate in organizations and continue to work. In this context, it can be claimed that the attitudes of people toward their professions define their attitudes toward their organizations. When the individual and professional expectations of people are not satisfied, they become less committed to their employers and organizations and more willing to quit them. The commitment of such personnel will be to their occupations, carriers and/or professions rather than the organization. The opposite can also happen. It is possible that individuals keep their commitment to their professions and feels affective and normative commitment to their organization when their professional expectations are satisfied, and their professional goals and values match with those of the organization. In this case, the organization deserves the commitment of the individuals since it helps them do their jobs in the best way and develop themselves. This view also supports the notion that the professi- onal commitment of the individual will be lower if the organizational commitment of him depends on self-interest.

Like the other studies in the literature (Koeske and Koeske, 1993, p.107-135; Lee, et al., 2000, p.799-811), a positive medium level relationship was found between professional commitment and work commitment in our study. In other words, as the professional commitment of an individual increases, so does his work commitment, and as his professional commitment decreases, so does his work commitment. Individuals who are more willing to stay in the profession, accept its goals and values, and exert effort on behalf of it are more likely to commit themselves to work hard and identify with their jobs because their jobs are an important tool for them to perform their professions, which are important to them.

In many studies on the relationship between work commitment and organizational commitment, a positive medium level relationship was found between these two variables (e.g., Porter, et al., 1976, p.87-98; Cook and Wall, 1980, p.39-52; Morrow, 1983, p.486500; Parasuraman and Nachman, 1987, p.287-303; Blau and Boal, 1989, p.115-127; Knoop, 1995, p.643649; Taşkıran and Özcan 2007, p.402-500; Buchko, et al., 1998, p.109-116; Ceylan and Demircan, 2002, p.1-13; Thomas, 2002, p.143-286). In our study, a positive low level relationship was found between affective and normative commitment to organization and 
work commitment. Moreover, it was observed that organizational commitment based on self-interest and necessity does not have a statistically significant relationship with work commitment. It can be stated that belonging feeling and ethic understanding which lead to affective and normative commitment to the organization can be a factor diminishing the effect of stressful working conditions of the nurses (Namasivayam and Zhao, 2007, 1212-1223) and this can increase work commitment. Those who feel high levels of both work commitment and organizational commitment are also highly motivated individuals. Such individual's meet both their inner needs and the social and external needs of the organization they work for (Huffman, 1997, p.211-219).

In most of the previous studies, the existence of a negative relationship between family commitment, professional commitment and work commitment was asserted (Powell and Mainiero, 1992, p.215-237; Higgins, et al., 1992, p.51-75; Tenbrunsel, et al., 1995, 233-246; Stroh, et al., 1996, p.99-118; Allen, et al., 2000, p.278-308; Martins, et al., 2002, p.399-409; Frone, 2003, p.143-162). In our study, no statistically significant relationship was found between family commitment and professional commitment. This shows that the individuals perceive their family and professional roles separately. Theoretically, women and men prioritize their work and family life roles differently. All the participant nurses of our study are women. The studies show that women generally put their family relations at the top of their priorities (e.g., Veiga, 1983, p.64-85; Tenbrunsel, et al., 1995, p.233-246). This situation is more apparent in women brought up in Turkish culture. The women who put their families at the top of their priorities tolerate work-family clash less (Bardwick, 1986, p.135-155). In other words, since family roles always come first for women, they clash with their professional commitment.

Moreover, our analysis results indicate that there is a positive weak relationship between family commitment and work commitment. This can be viewed as a result contrary to what the literature generally suggests. However, in the literature there are also a few studies, which show that this situation is possible, and different life roles of the individuals can support each other. This situation can be explained with work life integration defined by Friedman and Greenhaus (2000, p.101-188) or work life facilitation defined by Frone, (2003, p.143-162). According to Friedman and
Greenhaus (2000, p.101-188), work life facilitation takes places when a role positively affects another role, and a gain (such as money, flexibility, self-confidence and knowledge) is achieved. Facilitation occurs when a negative experience in a role is facilitated through positive experiences in a role (Greenhaus, et al., 2003, p.510-531). The outcomes of work life facilitation are listed as increased physical health, better relations, higher professional commitment, increased productivity and job satisfaction (O'Driscoll, et al., 2006, p.117-142).

Further, in our study, work commitment has a positive relationship with professional commitment, affective and normative commitment to the organization and family commitment. However, it was observed that contrary to what Randall and Cote (1991, p.194-211) suggest, work commitment does not have a compatible role in inner relationships with other commitment forms.

To sum up, in the scope of the sampling of our research, it can be said that: 1) When the professional practices, ethical values and professional development of the nurses are supported, their affective and normative commitment to the organization increases. 2) Practices to increase continuance commitment of nurses to the organization weaken their professional commitment. 3) Supporting the professional practices, ethical values and professional development of the nurses increase their work commitment. 4) When nurses have affective and normative commitment to their organization, this leads to increase in work commitment. 5) Nurses can be committed to their families and works at the same time. These two roles support each other. It is possible to work on increasing the nurses' professional commitment, affective and normative commitment to the organization and work commitment at the same time at hospitals. Although these concepts are basically different from each other, they do not clash with each other, on the contrary they support each other.

\section{Study Limitations}

One of the limitations of this study is that the sample is confined to a metropolis and nurses employed to hospitals with 500 or over bed capacity. It is possible to get different results if the same study is conducted in different regions and different samples. Therefore, the results should be taken into consideration limited to this sample. 
The professional commitment level of the nurses involved in the sample is low. This situation can stem from the features of the profession and the professional choice and education of the nurses in Turkey. It would have been possible to get different results if the professional commitment of the sample was high.

\section{Conclusion}

As a result of the insight gained at the end of this study, we believe that it will be useful if hospitals work on increasing the nurses' professional commitment, affective and normative commitment to the organization and work commitment at the same time, and the same research is conducted a few years later to see the results.

Commitment to different focuses handled in this study tends to be affected from professional features, working conditions and cultural and social structure. Therefore, we believe that conducting a similar study with nurses in a different social structure and culture will be beneficial since it will provide the opportunity to make comparisons.

\section{References}

Aldous, J., Osmond, M.W., Hicks, M.W. (1979). Economic Distress, Social Integration, and Family Satisfaction. In Wesley R. Burr, Reuben Hill, F. Ivan Nye, and Ira L. Reiss (eds.), Contemporary Theories About The Family, New York: Free Press, (1), 227-325.

Allen, T.D., Herst, D.E.L., Bruck, C.S., Sutton, M. (2000). Consequences Associated with Work-toFamily Conflict: A Review and Agenda for Future Research. Journal of Occupational Health Psycho$\log y, 5$ (2), 278-308.

Bardwick, J.M. (1986). The Plateauing Trap: How to Avoid it in Your Career... and Your Life. New York: American Management Association.

Becker, H.S. (1960). Notes on The Concept of Commitment. The American Journal of Sociology, 66 (1), $32-42$.

Berger, P.K., Grimes, A.J. (1973). Cosmopolitan-local: A Factor Analysis of The Construct. Administrative Science Quarterly, 18 (2), 223-235.
Billingsley, B.S., Cross, L.H. (1992). Predictors of Commitment, Job Satisfaction, and Intent to Stay in Teaching: A Comparison of General and Special Educators. Journal of Special Education, 25 (4), 453-471.

Blau, G.J. (1985). The Measurement and Prediction of Career Commitment. Journal of Occupational Psychology, 58 (4), 277-288.

Blau, G.J., Boal, K. (1989). Using Job Involvement and Organizational Commitment Interactively to Predict Turnover. Journal of Management, 15 (1), 115127.

Bredeson, P.V., Fruth, M.J., Kasten, K.L. (1983). Organizational Incentives and Secondary School Teaching. Journal of Research and Development in Education, 16 (4), 52-58.

Buchko, A.A.,Weinzimmer, L.G., Sergeyev, A.V. (1998). Effects of Cultural Context on The Antecedents, Correlates and Consequences of Organizational Commitment: A Study of Russian Workers. Journal of Business Research, 43 (3), 109-116.

Carmeli, A. (2003). The Relationship Between Emotional Intelligence and Work Attitudes, Behaviour and Outcomes. Journal of Managerial Psychology, 18 (8), 788-813.

Carson, K.D., Carson, P.P., Roe, W.C., Phillips, J.S. (1996). A Career Entrenchment Model: Theoretical Development and Empirical Outcomes. Journal of Career Development, 22 (4), 273-286.

Ceylan, A., Nigar D. (2002). Çalışanların Örgüte Bağlılığ 1 ile İşten Ayrılma Niyeti Arasındaki İlişkilere Yönelik Bir Araştırma. İÜ İşletme Fakültesi Dergisi, 31(1), 1-13.

Cheng, E.W.L. (2001). SEM Being More Effective Than Multiple Regression in Parsimonious Model Testing for Management Devolopment Research. Journal of Management Development, 20 (7), 650667.

Cohen, A. (1999). Relationships Among Five Forms of Commitment: An Empirical Assessment. Journal of Organizational Behavior, 20 (3), 285-308.

Cohen, A. (2000). The Relationship Between Commitment Forms and Work Outcomes: A Comparison of Three Models. Human Relations, 53 (3); 387-417. 
Cook, J.D., Wall, T.D. (1980). New Work Attitude Measures of Trust, Organizational Commitment and Personal Need Non-Fulfilment. Journal of Occupational Psychology, 53 (3), 39-52.

Dubin, R. (1956). Industrial Workers' Worlds: A Study of The Central Life Interests of Industrial Workers. Social Problems, 3 (3), 131-142.

Firestone, W.A., Pennell, J.R. (1993). Teacher Commitment, Working Conditions, and Differential Incentive Policies. Review of Educational Research, 63 (4), 489-525.

Flango, V.E., Brumbaugh, R.B. (1974). The Dimensionality of The Cosmopolitan-Local Construct. Administrative Science Quarterly, 19 (2), 198-210.

Friedlander, F. (1971). Performance and Orientation Structures of Research Scientists. Organization Behavior and Human Performance, 6 (2), 169-183.

Friedman, S.D., Greenhaus, J.H. (2000). Work and Family-Allies or Enemies? What Happens When Business Professionals Confront Life Choices. New York, NY: Oxford University Press.

Frone M.R., Russell, M., Cooper, M.L. (1992). Antecedents and Outcomes of Work Family Conflict: Testing A Model of The Work Family Interface. Journal of Applied Psychology, 77(1), 65-78.

Frone, M.R. (2003). Work-Family Balance. In Quick, J. C. and Tetrick, L. E. (Eds.), Handbook of Occupational Health Psychology, 143-162, Washington, DC: American Psychological Association.

Greenhaus, J.H., Collins, K.H. M., Shaw, J.D. (2003). The Relation Between Work-Family Balance and Quality of Life. Journal of Vocational Behavior, 63 (3), 510-531.

Greenhouse, J.H. (1971). An Investigation of The Role of Career Salience in Vocational Behaviour. Journal of Vocational Behaviour, 1 (3), 209-216.

Grimes, A.J. (1980). Cosmopolitian-Local: A Multidimensional Construct. Research in Higher Education, 13 (3), 195-211.

Higgins, C.A., Duxburry, L.E., Irving, R.H. (1992). Work Family Conflict in The Dual Career Family. Organizational Behavior and Human Decision Processes, 51 (1), 51-75.
Huffman, T.E. (1997). The Transculturation of Native American Students. In J.J. Macionis and N.V. Benokraitis (Eds.), Seeing ourselves: Classic, Contemporary, and Cross-Cultural Readings in Sociology (4th ed.), Upper River, NJ: Prentice-Hall, 211-219.

Igbaria, M. (1991). Job Performance of MIS Professionals: An Examination of The Antecedents and Consequences. Journal of Engineering and Tecnology Management, 8 (2), 141-171.

Joreskog, K., Sörbom, D. (2001). Lisrel 8: User's Reference Guide. Chicago: Scientific Software International Inc.

Kanungo, R.N. (1982). Measurement of Job and Work Involvement. Journal of Applied Psychology, 67 (3), 341-349.

Knoop, R. (1995). Relationships Among Job Involvement, Job Satisfaction and Organizational Commitment for Nurses. The Journal of Psychology, 129(6), 643-649.

Koeske, G.F., Koeske, R.D. (1993). A Preliminary Test of A Stress-Strain-Outcome Model for Reconceptualizing The Burnout Phenomenon. Journal of Social Service Research, 17 (3\&4), 107 - 135.

Lachman, R., Aranya, N. (1986). Evaluation of Alternative Models of Commitments and Job Attitudes of Professionals. Journal of Organizational Behavior. 7 (3), $227-243$.

Lawler, E.E., Hall, D.T. (1970). Relationship of Job Characteristics to Job Involvement, Satisfaction, and Intrinsic Motivation. Journal of Applied Psychology, 54 (4), 305-312.

Lee, K., Carswell, J.J., Allen, N.J. (2000). A MetaAnalytic Review of Occupational Commitment: Relations with Person-and Work-Related Variables. Journal of Applied Psychology, 85 (5), 799-811.

Lodahl, T,M., Kejner, M. (1965). The Definition and Measurement of Job Involvement. Journal of Applied Psychology, 49 (1), 24-33.

MacLean, S., Gray, K. (1998). Structural Equation Modeling in Market Research. Journal of the Australian Market Research Society, Retrieved September 26, 2001, from www: http://www.smallwaters. com/whitepapers/marketing. 
Manheim, B., Papo, E. (2000). Differences in Organizational Commitment and Its Correlates Among Professional and Nonprofessional Occupational Welfare Workers. Administration in Social Work, 23 (3\&4), 119-137.

Martins, L.L., Eddleston, K.A., Veiga, J.F. (2002). Moderators of The Relationship Between WorkFamily Conflict and Career Satisfaction. The Academy of Management Journal, 45 (2), 399-409.

Mathieu, J.E., Zajac, D.M. (1990). A Review and Meta-Analysis of The Antecedents, Correlates, and Consequences of Organizational Commitment. Psychological Bulletin, 108 (2), 171-94.

Meyer J.P., Allen N.J. (1991). A Three-Component Conceptualization of Organizational Commitment. Human Resources Management Review, 1 (1), 61-89.

Meyer J.P., Allen N.J. (1997) Commitment in The Workplace, Theory, Research and Application. London: Sage Publications, Inc.

Meyer, J.P., Stanley D.J., Herscovitch, L., Topolnytsky, L. (2002). Affective, Continuance and Normative Commitment to The Organization: A Meta - Analysis of Antecedents, Correlates and Consequences. Journal of Vocational Behavior, 61 (1), 20 - 52.

Morris, J.H., Sherman, J.D. (1981). Generalizability of Organisational Commitment Model. Academy of Management Journal, 24 (3), 512-526.

Morrow, P.C. (1983). Concept Redundancy In Organizational Research: The Case of Work Commitment. The Academy of Management Review, Vol. 8 (3), 486-500.

Morrow, P.C.,(1993). The Theory and Measurement of Work Commitment. Greenwich, Conn. : JAI Press.

Namasivayam K., Zhao X-M. (2007). An Investigation of The Moderating Effects of Organizational Commitment on The Relationships Between WorkFamily Conflict and Job Satisfaction Among Hospitality Employees in India. Tourism Management, 28 (6), 1212-1223.

O’Driscoll, M., Brough, P., Kalliath, T. (2006). WorkFamily Conflict and Facilitation. In F. Jones, R. Burke and M.Westman (Eds.). Work-life balance: A psychological perspective. Hove, United Kingdom: Psychology Press, 117-142.
Pang, N.S.K. (1996). School Values and Teachers' Feelings: A Lisrel Model. Journal of Educational Administration, 34 (2), 64-83.

Parasuraman, S., Nachman, S. (1987). Correlates of Organizational and Professional Commitment. Group and Organization Studies, 12 (3), 287-303.

Paullay, I.M., Alliger, G.M., Stone-Romero, E.F. (1994). Construct Validation of Two Instruments Designed to Measure Job Involvement and Work Centrality. Journal of Applied Psychology, 79 (2), 224-228.

Porter, L.W., Crampon, W.J., Smith, F.J. (1976). Organizational Commitment and Managerial Turnovers: A Longitudinal Study. Organizational Behavior and Human Performance, 15 (1), 87-98.

Powell, G.N., Mainiero, L.A. (1992). Cross-Currents in The River of Time: Conceptualizing The Complexities of Women's Careers. Journal of Management, 18 (2), 215-237.

Price-Bonham, S., Murphy, D.C. (1980). Dual-Career Marriages: Implications for The Clinician. Journal of Marital and Family Therapy, 6 (2), 181-188.

Randall, D.M., Cote, J.A. (1991). Interrelationships of Work Commitment Constructs. Work and Occupation, 18 (2), 194-211.

Reisinger, Y., Turner, L. (1999). Structural Equation Modeling with LISREL: Aplication in Tourism. Tourism Management, 20 (1),71-88.

Rice, D.G. (1979). Interaction patterns: Dual-Career Spouses. In James M. Henslin (ed.), Marriage and Family in a Changing Society. New York: Free Press.

Rusbult, C.E., Farrel, D. (1983). A Longitudinal Test of The Investment Model: The Impact on Job Satisfaction, Job Commitment and Turnover of Variations in Rewards, Costs, Alternatives and Investments. Journal of Applied Psychology, 68 (3), 429-438.

Samuel O.S. (2007). Relationship Between Work-Family Conflicts and Work Attitudes Among Secondary School Teachers in Southwest Nigeria. European Journal of Scientific Research, 18 (3), 551-560.

Schermelleh-Engel, K., Moosbrugger, H. (2003). Evaluating The Fit of Structural Equation Models: Tests of Significance and Descriptive Goodnessof-Fit Measures. Methods of Psychological Research Online, 8 (2), 23-74. 
Skinner, D.A. (1983). Dual-career families: Strains of Sharing. In Hamilton I. McCubbin and Charles R. Figley (eds.), Stress and the Family. New York: Brunner/Mazel, 1, 90-101.

Snape, E., Redman, T. (2003). An Evaluation of A Three-Component Model of Occupational Commitment: Dimensionality and Consequences Among United Kingdom Human Resource Management Specialists Journal of Applied Psychology, 88 (1), 152-159.

Stroh, L., Brett, J.M., Reilly, A.H. (1996). Family Structure, Glass Ceiling And Traditional Explanations for The Differential Rate of Turnover of Female and Male Managers. Journal of Vocational Behavior, 49 (1), 99-118.

Taşkıran, E., Dinç Ö.E. (2007). Örgüte Bağlllık ile İşe Bağlllık Arasındaki İlişkinin İncelenmesine Yönelik Hizmet Sektöründe Bir Araştırma. 15. Yönetim ve Organizasyon Kongresi, 25-27 Mayıs, Sakarya, 402-500.

Tenbrunsel, A.E., Brett, J.M.;Maoz, E., Stroh, L.K., Reilly, A.H. (1995). Dynamic and Static Work-Family Relationships. Organizational Behavior and $\mathrm{Hu}$ man Decision Processes, 63 (3), 233-246.

Thomas, D.C. (2002). Essentials of International Management: A Cross-Cultural Perspective. Thousand Oaks, CA: Sage.

Tuma, N.B., Grimes, A.J. (1981). A Comparison of Models of Role Orientations of Professionals in A Research- Oriented University. Administrative Science Quarterly, 26 (2), 187-206.
Vanderberg, R.J., Scarpello, V. (1994). A Longitudinal Assessment of The Determinant Relationship Between Employee Commitments to The Occupation and The Organization. Journal of Organizational Behavior, 15 (6), 535-547.

Veiga, J.F. (1983). Mobility Influences During Managerial Career Stages. Academy of Management Journal, 26 (1), 64-85.

Wallace, J.E. (1993). Professional and Organizational Commitment: Compatible or Incompatible? Journal of Vocational Behavior, 42 (3), 333-349.

Weick, K.E., McDaniel, R,R. (1989). How Professional Organizations Work: Implications for School Organization and Management. In T. J. Sergiovanni \& J. H. Moore (Eds.), Schooling for tomorrow: Directing reforms to issues that count, Needham Heights, MA:Allyn \& Bacon, 331-354.

Wiley, D.L. (1987). The Relationship Between Work Nonwork Role Conflict and Job Related Outcomes: Some Unanticipated Outcomes. Journal of Management, 13 (3), 467-472.

Yogev, S., Brett, J. (1985). Patterns of Work and Family Involvement Among Single and Dual-Earner Couples. Journal of Applied Psychology, 70 (4), 754768.

Zin, R.B.M. (2006). The Relationships Between Family and Career-Related Factors and Organizational Commitment: A Malaysian Case. The Business Review, 5 (2), 117-121. 